\title{
Editorial: Outlook on the future contribution of museums to the history of construction engineering
}

Dirk Bühler Dr-Ing

Deutsches Museum, Munich, Germany

The permanent collections of many museums, including the museums of science and technology at the Deutsches Museum in Munich, can often serve as places for the study of civil and building engineering history in addition to the museums' temporary exhibitions and their various educational initiatives. They can, for example, present the physical basis for structural analysis related to different construction techniques on the one hand and, on the other, show models representing both historical and modern construction methods and examples of specific construction materials and their applications. Other galleries of the Deutsches Museum are devoted to topics such as surveying, and the production of materials in general. The visitor is conducted as a curious observer to a construction site.

An interesting and frequent observation in exhibitions devoted to construction is that, due to the schematic summary of the technical facts in an organised context, the particular task of a modern engineer can be comprehended better as part of an integrated general vision, of which many of us are not always conscious anymore, because we are working mostly on specific details.

What means of presenting the history of construction engineering are available? The first and most impressive one is always to show the original, if its size permits; if not, a model is a highly feasible and attractive alternative form of abstraction, reducing the original to its essential elements and distilling the original artifacts and processes to an instructive scale. Experiments may also be used to explain the basic structural facts.

The main challenge for the museum curator is to reduce complex construction processes to a comprehensible level (without undue simplification) for a general public or to a compendium for engineering students, including material such as diagrams and multimedia images. Creating an exhibition and undertaking the indispensable accompanying research is a scientific task for the curator and their advisory team. The exhibition finally makes visible to the public the results of the study of construction history through objects, models and the associated graphical and textual material.

The planning and building of models is an excellent scientific approach to the history of construction. First of all, the curator and the model builder have to determine the precise purpose of the presentation: whether it is educational for a specific public, reconstructive for historic preservation of a lost original, promotional for conservation of an existing construction, or for the rediscovery of historical manufacturing processes, and more besides. It makes a great difference if you want to show a process or a finished construction. In the first case, there is the choice of the best moment during the construction period in order to display the largest number of details that explain the process; this is an important scientific step. In the second case, when representing the finished construction, the decision will refer more to the desired historical state of a construction, the detailing of the model and the choice of a scale that is suitable for these ends. After this first decision - in both cases - reliable plans, photographs, graphics and the referring literature relevant to the chosen moment in the structure's life have to be found and consulted. The associated building equipment, construction materials and machinery have to be examined. All sizes, colours and materials for the model have to be selected and checked with the original. All these activities contribute finally to making the model a real contribution to the history of construction, not only because the model presents the result to the public, but also because the same complete documentation is required for the model as for the original. Many museums and public organisations undertake this strenuous task of reconstructing historic buildings with authentic tools, materials and procedures.

In addition to their exhibitions, the museums' collections can represent an inestimable resource for study of construction history for students and researchers. One of the most comprehensive collections of objects and documents referring to construction techniques and their history is registered in the Deutsches Museum (Munich, Germany). Since its foundation in 1903 objects related to construction technology and their applications in civil engineering and architecture have been collected. Among them all possible examples of construction materials, their production and their use are displayed, along with the necessary testing devices, the production methods, the possible applications, the surface treatment and final implementation in buildings. Due to the fact that the museum's founder, Oskar von Miller, was a civil engineer and very involved in concrete construction in hydraulic power plants, the Museum is one of the major concrete constructions in Munich 
from the beginning of the twentieth century. What is more, for this reason the main focus of the collection is an assortment of instruments for testing cement and concrete, specimens of concrete types and surface treatment, devices for the production of cement and concrete and, finally, many models showing concrete construction sites and finished buildings.

This collection dates back to the late nineteenth century, the first days of the general modern use of concrete in engineering and architecture. Since collecting has continued up to modern times the collection includes objects up until the late 1960s, donated by the German firm DYWIDAG, and even some objects from the present day. With regard to construction history, there are more areas represented in the collection of the Deutsches Museum, such as the production, processing and use of brick, steel and wood, and their application in bridge and road construction, hydraulic engineering and high-rise building. Construction plant and equipment have been and are still being collected. These collections of objects are complemented by an extensive specialised library and large archives. All the results of the research undertaken for objects and exhibitions are published by the Museum. This fund of exhibitions, objects treasured in the collections, printed documents and literature in the library, and manuscripts in the archives of the Deutsches Museum makes this institution a wonderful place for future studies on construction history.

Of course, the Deutsches Museum (http://www.deutsches-museum. de) is not the only one to collect, exhibit and study objects relevant to construction history, even if it maintains one of the most complete collections on the subject. The collection of the Musee des Arts et Métiers in Paris (http://www.arts-et-metiers.net) is probably smaller but no less important for its old age and for its representative samples of French engineering. The Cité de l'Architecture et du Patrimoine in the Palais de Chaillot in Paris (http://www.citechaillot. fr/en) shows an enormous collection of plaster casts of French historical architecture initiated by Viollet le Duc on the ground floor, and modern architecture in the second. And it exhibits not only architecture but also some of the related manufacturing techniques with originals, models and elementary experiments. The Deutsches Technikmuseum in Berlin (http://www.sdtb.de/English. 122.0.html) has its main focus on railway construction and features some related structures such as stations and bridges. However, many other technical museums do not collect construction history at all. The Science Museum in London (http://www.sciencemuseum. org.uk), for instance, does not have a construction collection except for a few objects as part of the collection on materials.

In the USA, the National Building Museum in Washington, DC (http://www.nbm.org) presents exhibitions and offers educational and scientific activities related to construction history. The museum owns a permanent collection that illuminates the building process and construction techniques. The collections contain approximately
75000 photographic images, 68000 architectural prints and drawings, 100 linear feet of documents and 10000 objects, including material samples, architectural fragments and building toys.

Referring to specific construction materials there are museums dedicated to cements, usually related to ancient, abandoned cement factories, and brick museums usually related to an outdoor museum of typical regional architecture. The most interesting of these in Germany is perhaps the museum in Bad Windsheim (http://www. freilandmuseum.de/startseite.html) where historical bricks are remade using traditional methods and are then used in the restoration of historical buildings. As a result this museum operates not just as an educational institution but also as a supporting establishment for the study of construction history and the conservation and restoration of our cultural heritage, including the engineering part.

In Great Britain, the Weald and Downland Open Air Museum (http://www.wealddown.co.uk), opened in 1970, established a centre that rescues representative examples of vernacular buildings from the south-east of England. The museum promotes the retention of buildings on their original sites unless there is no alternative, and it encourages an informed and sympathetic approach to their preservation and continuing use. Furthermore, the museum offers advice to people involved in the conservation of buildings. As well as illustrating the history of original building styles and types, the museum has collections representing country crafts and industries, building trades and agriculture.

A spectacular centre for research and presentation of construction history exists in the heart of Puisaye, in Yonne, Burgundy, France (http://www.guedelon.fr/en/the-guedelon-adventure_01.html), where a team of 50 people has taken on an extraordinary feat: to build a castle using the same techniques and materials used in the Middle Ages. The wood, stone, earth, sand and clay needed for the castle's construction are all to be found here, in this abandoned quarry. Watched by thousands of visitors, all the trades associated with castle-building are all working together to complete the castle. Work on the site began in 1997 and is scheduled to take 25 years to complete. The site offers something for everyone: archaeologists, historians, teachers, students and families.

Another important contribution to construction history is provided by the many site museums built close to well-known engineering monuments, like the one near Iron Bridge in Coalbrookdale, UK or the Brooklyn Bridge Museum in New York, NY, USA. Other more recent museums include the ones built close to the Great Belt Bridge in Denmark and the Akashi-Kaikyo Bridge in Japan, where the structures themselves are explained in detail.

It is astonishing, perhaps, that architectural museums do not usually exhibit, collect or study what we understand as construction history, probably because they are more focused on constructions as designed spaces than as technical museums. 
An elaborate compendium on this kind of museum is offered in the Building Museums Guide by Tim Ostler (1993). In Germany, the Ingenieurbau Führer Baden-Württemberg, written by Jörg Schlaich and Matthias Schüller and edited by the Ingenieurkammer BadenWürttemberg, set standards (Schlaich and Schüller, 1999). An online guide to architecture and civil engineering structures in North Rhine-Westphalia is available at www.baukunst-nrw.de.

Finally, museum buildings themselves often serve as objects for research in construction history in order to facilitate their maintenance and, even more, during their restoration. The case of the reconstruction of the Neues Museum in Berlin provides a spectacular contribution: the museum, recently restored, presents consciously the results of this research as a palpable reference in their galleries. Gerhard Eisele and Josef Seiler explained in their award-winning article (Eisele and Seiler, 2012) how a thorough understanding of historic structures and conservation objectives is the key for proper handling of buildings with high conservation significance.

In conclusion I would like to make a plea for all students, researchers and professors in the field of the history of construction to make more frequently intensive use of all the material offered generously by the museums: it will be worthwhile!

\section{Papers in this issue}

The papers in this issue feature a wide range of projects spanning many centuries and several continents. The first, by Zhang et al. (2014), tells the remarkable story of the Grand Canal in China which was begun about 2500 years ago. The Qingkou complex was the culmination of the feat, constructed between the sixteenth and nineteenth centuries $\mathrm{AD}$ to manage the huge quantities of water of the Huai River, the Yellow River and the Grand Canal. Constructed over such a long time, the complex has had to deal with changes in the courses of rivers, the trade on the canal and even the climate and is an example of hydraulic engineering on a monumental scale. The complex has been restored and reconstructed many times for entirely functional reasons as well as, more recently, heritage reasons.

The islands of Sardinia and Corsica have been occupied and ruled by many different countries for much of their histories. One consequence of this has been a large number of military structures overlooking the waters that separate the islands. In her paper Stefania Murru (2014) describes a multidisciplinary investigation of some of the several hundred observation towers that survive. By bringing together the different skills and approaches of geologists, archaeologists, archivists, historians, engineers, architects and surveyors, a detailed picture has been built up of how the towers were constructed and where the materials and construction skills came from. The results are being used to help understand the historical context and significance of these towers, and to guide the restoration of many of them.
From one type of coastal structure to another - a Victorian seaside pier at Brighton on the south coast of England. Building a structure in the sea is an extremely harsh environment and it is, frankly, remarkable that so many Victorian piers, including this one, survive today. Although cast and wrought iron are more resistant to corrosion that steel, they deteriorate nevertheless and, during a century, some structural members have been eaten away almost entirely. John Winterbottom (2014) describes the immense challenges faced by the engineers in assessing the damage to the structure and devising repair solutions that could be carried out, while the public entertainment activities continued uninterrupted above.

For more than half a century now, few people in Europe have experienced the vital role that engineers play in war. Begbie and Roberts (2014) recount the remarkable contribution engineers made to the British war effort in providing temporary bridges for men and equipment. The Bailey bridge is well known, but this was only one of many types of structure used in many different situations. The way that engineers responded to the urgency of military bridge-building, together with the limited resources and adverse conditions, can still be an inspiration to today's engineers about what is possible in extreme circumstances.

\section{REFERENCES}

Begbie D and Roberts G (2014) Bridging in the Second World War: an imperative to victory. Proceedings of the Institution of Civil Engineers - Engineering History and Heritage 167(2): 111-121, http://dx.doi.org/10.1680/ehah.13.00022.

Eisele G and Seiler J (2012) Reconstruction of the Neues Museum in Berlin, Germany. Proceedings of the Institution of Civil Engineers - Engineering History and Heritage 165(4): 221-233, http://dx.doi.org/10.1680/ehah. 11.00013.

Murru S (2014) Investigating 500-year-old coastal towers in Sardinia and Corsica: a research protocol. Proceedings of the Institution of Civil Engineers - Engineering History and Heritage 167(2): 88-99, http://dx.doi.org/10.1680/ehah.13. 00030.

Ostler T (1993) The Building Museums Guide. Interbuild Publications, London, UK.

Schlaich J and Schüller M (1999) Ingenieurbau Führer BadenWürttemberg (Ingenieurkammer Baden-Württemberg (ed.)) Bauwerk Verlag, Berlin, Germany.

Winterbottom N (2014) Brighton Pier, UK - innovation in renovation. Proceedings of the Institution of Civil Engineers - Engineering History and Heritage 167(2): 100-110, http://dx.doi.org/10.1680/ehah.13.00025.

Zhang J, Zhao Y, Wang Z et al. (2014) Qingkou complex: an engineering masterpiece of the Grand Canal of China. Proceedings of the Institution of Civil Engineers Engineering History and Heritage 167(2): 74-87, http://dx. doi.org/10.1680/ehah.13.00028. 